\title{
Average Daily Temperature and Reversed Day/Night Temperature Regulate Vegetative and Reproductive Responses of a Doritis pulcherrima Lindley Hybrid
}

\author{
Yin-Tung Wang \\ Department of Horticultural Sciences, Texas A\&M University System \\ Agricultural Research and Extension Center, 2415 East Highway 83, \\ Weslaco, TX 78596
}

Additional index words. Doritis pulcherrima, development, flowering, morphology

\begin{abstract}
It was unknown how prolonged periods of cool days and warm nights affect Phalaenopsis Blume hybrids, which perform crassulacean acid metabolism and absorb $\mathrm{CO}_{2}$ primarily at night. The 'Lava Glow' plants vegetatively propagated from a hybrid Doritaenopsis (Phalaenopsis Buddha's Treasure $\times$ Doritis pulcherrima Lindley*), $15 \mathrm{~cm}$ in leaf span, were grown at day/night (12 hours each daily) temperatures of 30/25, 25/30, 25/ 20 , or $20 / 25{ }^{\circ} \mathrm{C}$ under $170 \mu \mathrm{mol} \cdot \mathrm{m}^{-2} \cdot \mathrm{s}^{-1} \mathrm{PPF}$. After 37 weeks, plants at the higher average daily temperature of $27.5{ }^{\circ} \mathrm{C}\left(\mathrm{ADT}, 30 / 25\right.$ and $\left.25 / 30{ }^{\circ} \mathrm{C}\right)$ produced more leaves than the lower $22.5{ }^{\circ} \mathrm{C}$ ADT. Those grown at $30 / 25{ }^{\circ} \mathrm{C}$ had the largest leaf span and combined length of the new leaves. Plants at 30/25, 25/30, 25/20, or $20 / 25^{\circ} \mathrm{C}$ had 5.0, 4.7, 3.6, and 2.8 new leaves that were $72,61,44$, and $29 \mathrm{~cm}$ in total length, respectively. Warmer nights than days resulted in a small leaf span, reduced leaf growth, and shorter leaves that were particularly noticeable at the $22.5^{\circ} \mathrm{C}$ compared with $27.5^{\circ} \mathrm{C}$ ADT. Leaves that emerged and grew at the lower ADT had a reduced length to width ratio and a more oval shape. The most striking effect of the $20 / 25{ }^{\circ} \mathrm{C}$ treatment was that 14 of 15 plants bloomed, whereas only five plants at $25 / 20{ }^{\circ} \mathrm{C}$ and none at $30 / 25$ or $25 / 30{ }^{\circ} \mathrm{C}$ produced flowers. Similar results were obtained in a second experiment using 30/20, 20/30, 25/15, or 15/25 ${ }^{\circ} \mathrm{C}$. After 29 weeks, all plants at $15 / 25^{\circ} \mathrm{C}$ bloomed, whereas none in the other treatments had flowers. Long-term exposure to $15 / 25{ }^{\circ} \mathrm{C}$ resulted in slow leaf production and undesirable small leaves. These results suggest that day and night temperature may both affect growth and flowering of this orchid.
\end{abstract}

Potted orchids have become one of the most important potted floral crop in the United States with a wholesale value of \$144 million in 2005 (USDA, 2006) and worldwide (Wang, 2004), particularly the hybrid Phalaenopsis. Young plants of Phalaenopsis and Doritaenopsis (intergeneric hybrids between Phalaenopsis species and Doritis pulcherrima Lindley and between their hybrids or species) require a relatively warm environment to grow quickly (Krizek and Lawson, 1974; Lee, 1991; Lee and Lin, 1984; Lin and Lee, 1988; Wang, 2005). However, once plants have reached maturity, a relatively cool environment $\left(15\right.$ to $\left.25^{\circ} \mathrm{C}\right)$ is needed to promote the emergence of flowering stems (spiking) (Lee and Lin, 1984; Sakanishi et al., 1980). Phalaenopsis and Doritaenopsis perform crassulacean acid metabolism to fix $\mathrm{CO}_{2}$ primarily during the dark period of the day (Guo, 1999; Ota et al.,

Received for publication 31 May 2006. Accepted for publication 10 Aug. 2006.

E-mail yt-wang@tamu.edu

* Doritis pulcherrima Lindley has been reclassified as Phalaenopsis pulcherrima (Lindl.) J. J. Sm. (Christenson, 2001). and $10 \%$ each of Canadian sphagnum peat, large grade perlite, and dust sphagnum moss. The substrate was amended with $6 \mathrm{~g} \cdot \mathrm{L}^{-1}$ powdered dolomitic limestone and $1 \mathrm{~g} \cdot \mathrm{L}^{-1}$ of Micromax (a micronutrient source; Scotts, Inc., Marysville, Ohio). Plants were selected for their uniformity in overall size and distributed evenly to four blocks by the size of the newest, growing leaf, which was marked. Plants were moved to and remained in four growth chambers (Model EGC15; Environmental Growth Chambers, Chagrin Falls, Ohio) at $170 \mu \mathrm{mol} \cdot \mathrm{m}^{-2} \cdot \mathrm{s}^{-1} P P F$ with a 12-h photoperiod. Ninety percent of the irradiance was provided by cool-white fluorescent tubes and 10\% was from incandescent bulbs. There was no barrier between the light source and plants.

Treatments were day/night temperatures being maintained at $30 / 25,25 / 30,25 / 20$, or $20 / 25^{\circ} \mathrm{C}$ at $12 \mathrm{~h}$ each. In addition to a growth chamber's own temperature control system, temperatures were monitored with a hygrothermograph and a mercury thermometer in each chamber. $P P F$ in each chamber was monitored with a light meter frequently. Temperature and irradiance were adjusted when necessary.

Plants were fertigated when needed with a $15 \mathrm{~N}-2.3 \mathrm{P}-12.9 \mathrm{~K}$ soluble fertilizer (Scotts Inc.) at $0.67 \mathrm{~g} \cdot \mathrm{L}^{-1}$ with $33 \mathrm{mg} \cdot \mathrm{L}^{-1} \mathrm{Ca}$ and $13 \mathrm{mg} \cdot \mathrm{L}^{-1}$. After 37 weeks, leaf span (the distance between the tips of the two top leaves) was measured and the number of new leaves and their combined length were recorded. The length and width of the uppermost mature leaf were measured and their ratio was calculated. Plants were also observed for flowering. There were 15 plants per treatment.

Expt. 2. A second experiment was initiated on 21 May using the same clone, except they were in 14-cm standard pots. Plants 18 to $22 \mathrm{~cm}$ in leaf span were selected as previously stated and subjected to a wider day/ night temperature differential, including 30/ $20,20 / 30,25 / 15$, and $15 / 25^{\circ} \mathrm{C}$. Other environmental factors remained the same as in Expt. 1. Data were collected similar to this experiment after 29 weeks. There were 22 plants per temperature regimen. Analysis of variance was performed on the data in both experiments, except for number of plants flowered.

\section{Results}

Expt. 1. Plants at the higher average daily temperature (ADT, $27.5^{\circ} \mathrm{C}, 30 / 25^{\circ} \mathrm{C}$, or $25 /$ $30{ }^{\circ} \mathrm{C}$ ) produced more leaves than the ones at the lower ADT $\left(22.5{ }^{\circ} \mathrm{C}, 25 / 20{ }^{\circ} \mathrm{C}\right.$, or $20 / 25^{\circ} \mathrm{C}$ ) regardless of the day and night temperatures (Table 1). Those grown at $30 / 25^{\circ} \mathrm{C}$ had the widest leaf span and the largest total length of new leaves. For any given ADT, cooler days resulted in shorter total leaf length. At the higher ADT $\left(27.5^{\circ} \mathrm{C}\right)$, day and night temperatures did not affect the number of new leaves being produced. However, at the lower ADT $\left(22.5{ }^{\circ} \mathrm{C}\right)$, fewer leaves ( 2.8 versus 3.6$)$ were produced when days were cooler than the nights $\left(20 / 25^{\circ} \mathrm{C}\right)$. 
At any given ADT, cooler days resulted in shorter and narrower leaves, but the length and width ratio remained similar to that when the days were warmer (Table 2). Leaves that emerged and grew at the lower ADT had reduced length to width ratios than those at the higher ADT, giving more oval-shaped leaves. Although leaves produced at $25 / 30{ }^{\circ} \mathrm{C}$ or $25 / 20^{\circ} \mathrm{C}$ had similar lengths, those grown at $25 / 20{ }^{\circ} \mathrm{C}$ had a reduced length to width ratio.

Fourteen of 15 plants maintained at 20/25 ${ }^{\circ} \mathrm{C}$ flowered by the end of December, whereas only five plants in the $25 / 20^{\circ} \mathrm{C}$ treatment and none at the higher ADT $\left(27.5^{\circ} \mathrm{C}\right)$ bloomed (Table 2).

Expt. 2. Results from the second experiment were similar to the first one despite that the day/night differential was increased from $5{ }^{\circ} \mathrm{C}$ to $10{ }^{\circ} \mathrm{C}$. Although $30 / 20{ }^{\circ} \mathrm{C}$ and $20 / 30{ }^{\circ} \mathrm{C}$ resulted in similar numbers of new leaves being produced, those produced at $20 / 30{ }^{\circ} \mathrm{C}$ were shorter (Table 3). The small leaf span and lesser combined leaf length were dramatic at $15 / 25$ ${ }^{\circ} \mathrm{C}$ (Table 3). Despite the same ADT, new leaves produced at $15 / 25{ }^{\circ} \mathrm{C}$ were very small and only $50 \%$ the length of those at $25 / 15^{\circ} \mathrm{C}$ (Table 4; Fig. 1), giving a length to width ratio of 1.4, and a round appearance. These leaves were deeper green than leaves in other temperature regimen (Fig. 1). All 22 plants at $15 / 25^{\circ} \mathrm{C}$ bloomed, whereas none in the other three day/ night temperature regimen had flowers.

\section{Discussion}

Phalaenopsis performs crassulacean acid metabolism to assimilate $\mathrm{CO}_{2}$ primarily during the dark period of the day (Guo and Lee, 2006; Ota et al., 1991). Growing them at constant temperatures, Ota et al. (1991) determined that the net $\mathrm{CO}_{2}$ uptake by Phalaenopsis leaves during the 12-h light period decreased as temperature increased from $10{ }^{\circ} \mathrm{C}$ and declined to a very low level when temperatures reached or exceeded $25{ }^{\circ} \mathrm{C}$. $\mathrm{CO}_{2}$ uptake during the $12 \mathrm{~h}$ in darkness increased as temperature rose from $10^{\circ} \mathrm{C}$, reaching its plateau at $20^{\circ} \mathrm{C}$ and then declined as temperature increased further to $30^{\circ} \mathrm{C}$. However, when grown at different day/night temperatures, the daily cumulative $\mathrm{CO}_{2}$ up-

Table 1. Effects of various day/night temperatures on vegetative growth (Expt. 1)z.

\begin{tabular}{lccc}
\hline & & \multicolumn{2}{c}{ New leaves } \\
\cline { 2 - 3 } Treatment (day/night, $\left.{ }^{\circ} \mathrm{C}\right)$ & Leaf span $(\mathrm{cm})$ & $5.0 \mathrm{a}$ & Linear length $(\mathrm{cm})$ \\
\hline $30 / 25$ & $31.0 \mathrm{a}$ & $4.7 \mathrm{a}$ & $60.9 \mathrm{~b}$ \\
$25 / 30$ & $26.4 \mathrm{~b}$ & $3.6 \mathrm{~b}$ & $44.4 \mathrm{c}$ \\
$25 / 20$ & $25.4 \mathrm{~b}$ & $2.8 \mathrm{c}$ & $28.8 \mathrm{~d}$ \\
\hline
\end{tabular}

${ }^{\mathrm{z}}$ Means within columns followed by different letters are different by Duncan's multiple range test at $P \leq 0.05(\mathrm{n}=15)$.

Table 2. Effects of various day/night temperatures on leaf and flowering (Expt. 1) ${ }^{\mathrm{z}}$.

\begin{tabular}{lcccc}
\hline & \multicolumn{3}{c}{ Uppermost mature leaf } & No. of plants \\
\cline { 2 - 4 } Treatment (day/night, $\left.{ }^{\circ} \mathrm{C}\right)$ & Length $(\mathrm{cm})$ & Width $(\mathrm{cm})$ & L:W ratio & bloomed among 15 \\
\hline $30 / 25$ & $17.2 \mathrm{a}$ & $8.4 \mathrm{~b}$ & $2.04 \mathrm{a}$ & 0 \\
$25 / 30$ & $14.8 \mathrm{~b}$ & $7.6 \mathrm{c}$ & $1.95 \mathrm{a}$ & 0 \\
$25 / 20$ & $14.7 \mathrm{~b}$ & $9.0 \mathrm{a}$ & $1.63 \mathrm{~b}$ & 5 \\
$20 / 25$ & $11.1 \mathrm{c}$ & $7.3 \mathrm{c}$ & $1.52 \mathrm{~b}$ & 14 \\
\hline
\end{tabular}

${ }^{\mathrm{z}}$ Means within columns followed by different letters are different by Duncan's multiple range test at $P \leq 0.05(\mathrm{n}=15)$.

Table 3. Effects of $30 / 20,20 / 30,25 / 15$, and $15 / 25{ }^{\circ} \mathrm{C}$ day/night temperatures on vegetative growth (Expt. 2) $)^{\mathrm{z}}$

\begin{tabular}{lccc}
\hline & & \multicolumn{2}{c}{ New leaves } \\
\cline { 3 - 4 } Treatment (day/night, $\left.{ }^{\circ} \mathrm{C}\right)$ & Leaf span $(\mathrm{cm})$ & Number & Linear length $(\mathrm{cm})$ \\
\hline $30 / 20$ & $32.6 \mathrm{a}$ & $4.2 \mathrm{a}$ & $64.0 \mathrm{a}$ \\
$20 / 30$ & $26.4 \mathrm{~b}$ & $3.3 \mathrm{a}$ & $57.6 \mathrm{~b}$ \\
$25 / 15$ & $28.1 \mathrm{~b}$ & $3.4 \mathrm{~b}$ & $19.5 \mathrm{c}$ \\
$15 / 25$ & $16.7 \mathrm{c}$ & $2.1 \mathrm{c}$ & $19.5 \mathrm{~d}$ \\
\hline
\end{tabular}

${ }^{\mathrm{z}}$ Means within columns followed by different letters are different by Duncan's multiple range test at $P \leq 0.05(\mathrm{n}=22)$.

Table 4. Effects of $30 / 20,20 / 30,25 / 15$, and $15 / 25{ }^{\circ} \mathrm{C}$ day/night temperatures on leaf and flowering (Expt. 2)

\begin{tabular}{lcccc}
\hline & \multicolumn{3}{c}{ Uppermost mature leaf } & No. of plants \\
\cline { 2 - 5 } Treatment (day/night, $\left.{ }^{\circ} \mathrm{C}\right)$ & Length $(\mathrm{cm})$ & Width $(\mathrm{cm})$ & L:W ratio & bloomed among 22 \\
\hline $30 / 20$ & $18.3 \mathrm{a}$ & $8.7 \mathrm{~b}$ & $2.10 \mathrm{a}$ & 0 \\
$20 / 30$ & $14.7 \mathrm{c}$ & $7.9 \mathrm{c}$ & $1.86 \mathrm{~b}$ & 0 \\
$25 / 15$ & $16.4 \mathrm{~b}$ & $9.2 \mathrm{a}$ & $1.79 \mathrm{~b}$ & 0 \\
$15 / 25$ & $8.2 \mathrm{~d}$ & $7.1 \mathrm{~d}$ & $1.39 \mathrm{c}$ & 22 \\
\hline
\end{tabular}

${ }^{\mathrm{z}}$ Means within columns followed by different letters are different by Duncan's multiple range test at $P \leq 0.05(\mathrm{n}=22)$. take at $10 / 20{ }^{\circ} \mathrm{C}$ was much lower than that at $30 / 20,25 / 20$, or $25 / 15^{\circ} \mathrm{C}$ (Ota et al., 1991).

At a common $25{ }^{\circ} \mathrm{C}$ day temperature, Phalaenopsis leaves had higher level of $\mathrm{CO}_{2}$ absorption at $15{ }^{\circ} \mathrm{C}$ than at $25^{\circ} \mathrm{C}$ during the dark period (Ota et al., 1991). At a common night temperature of $15{ }^{\circ} \mathrm{C}$, daytime temperature of $25^{\circ} \mathrm{C}$ resulted in much higher total nighttime $\mathrm{CO}_{2}$ absorption than $15^{\circ} \mathrm{C}$. Lootens and Heursel (1998) reported that young Phalaenopsis plants had higher daily cumulative $\mathrm{CO}_{2}$ uptake at $20 / 15^{\circ} \mathrm{C}$ than at $25 / 20{ }^{\circ} \mathrm{C}$ or $25 / 25^{\circ} \mathrm{C}$, measured over a $24-\mathrm{h}$ period. However, Guo and Lee (2006) determined that Phalaenopsis leaves incorporated much higher quantities of $\mathrm{CO}_{2}$ at $32 / 28$ ${ }^{\circ} \mathrm{C}$ or $29 / 25^{\circ} \mathrm{C}$ than at $25 / 20{ }^{\circ} \mathrm{C}$ or $21 / 16{ }^{\circ} \mathrm{C}$ day/night temperatures. Guo and Lee (2006) and Lee and Lin (1984) clearly established that higher daily net $\mathrm{CO}_{2}$ uptake at higher temperatures $\left(15{ }^{\circ} \mathrm{C}\right.$ to $\left.32{ }^{\circ} \mathrm{C}\right)$ resulted in increased leaf growth in Pahalenopsis.

Maturation of the slow-growing Phalaenopsis is directly related to the rate of increase in cumulative leaf area (Lee, 1991). The current data support the findings of Lin and Lee (1988) that Phalaenopsis hybrids require high temperatures to grow quickly and produce more total leaf area at $30 / 25^{\circ} \mathrm{C}$ compared with $25 / 20{ }^{\circ} \mathrm{C}$ or $20 / 15{ }^{\circ} \mathrm{C}$. It is very clear that, for slow-growing plant species such as orchids, results from short-term experiments may not be a reliable tool for predicting the long-term growth response to certain environmental conditions.

The cool day/warm night temperature regimens of $20 / 25^{\circ} \mathrm{C}$ and $15 / 25^{\circ} \mathrm{C}$ markedly restricted vegetative growth. Because increased levels of soluble sugars in leaves have been associated with spiking (Lee and Lee, 1996), the current data suggest that there might have been increased sugar levels in leaves at the $20 / 25{ }^{\circ} \mathrm{C}$ and $15 / 25{ }^{\circ} \mathrm{C}$ conditions, which contributed to spiking and flowering. The photosynthetic response and levels of soluble sugars in the leaf at cool day/warm night conditions need to be studied in more detail to fully understand what contributed to flowering at these conditions.

Day/night air temperatures of $25 / 20{ }^{\circ} \mathrm{C}$ and $20 / 15{ }^{\circ} \mathrm{C}$ are capable of triggering spiking in Phalaenopsis and its hybrids

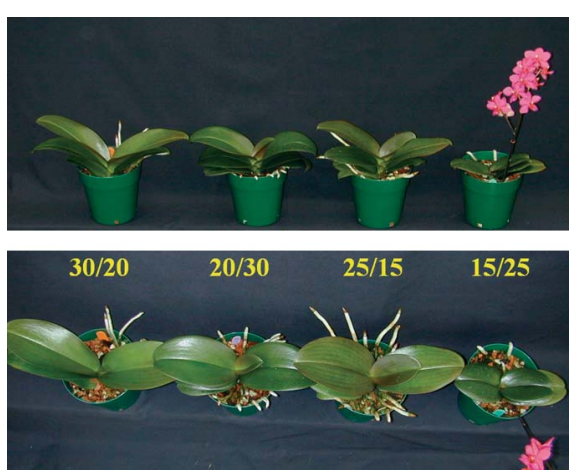

Fig. 1. Effect of day/night temperatures of 30/20, $20 / 30,25 / 15$, and $15 / 25^{\circ} \mathrm{C}$ on leaf growth and flowering. 
(Lee and Lin, 1984). However, $25 / 20^{\circ} \mathrm{C}$ in Expt. 1 only triggered one third of the plants to flower and $25 / 15{ }^{\circ} \mathrm{C}$ in Expt. 2 failed to trigger this cloned Doritaenopsis to start spiking. Surprisingly, with the same ADT, the reversed day/night temperatures (20/25 ${ }^{\circ} \mathrm{C}$ and $15 / 25^{\circ} \mathrm{C}$ ) effectively induced plants to flower under a 12-h photoperiod. Doritis pulcherrima naturally spikes in the spring rather than in the fall as Phalaenopsis or the large-flowered Doritaenopsis hybrids do. The Doritaenopsis used in this study is a first-generation hybrid of Doritis pulcherrima. As such, this Doritaenopsis clone may behave differently from Phalaenopsis or the more complex Doritaenopsis hybrids. More research is needed to fully understand the control mechanism for spiking in Phalaenopsis and Doritis species and hybrids.

The changes of leaf $\mathrm{L}: \mathrm{W}$ ratio in response not only to ADT, but to day/night temperatures clearly show the diurnal thermoregulation of plant morphology. The smaller leaf $\mathrm{L}: \mathrm{W}$ ratio at lower temperatures is in agreement to that observed by Lin and Lee (1988).

Results from this study clearly show the marked diurnal thermoregulation of plant growth and development. Having the day temperature in the $25^{\circ} \mathrm{C}$ to $15^{\circ} \mathrm{C}$ range, a prolonged period of nights being $5^{\circ} \mathrm{C}$ to 10
${ }^{\circ} \mathrm{C}$ warmer does not appear to enhance the accumulation of photosynthetic products and is not favorable for rapid vegetative growth. However, cool days and warm nights may be used as an effective tool for inducing spiking in certain hybrids. Additional studies are needed to learn if other Phalaenopsis species and hybrids respond similarly to the reversed day/night temperatures as this first generation Doritis pulcherrima hybrid.

\section{Literature Cited}

Christenson, C.A. 2001. Phalaenopsis-A monograph. Timber Press, Portland, Ore.

Guo, W.J. and N. Lee. 2006. Effect of leaf and plant age and day/night temperature on net $\mathrm{CO}_{2}$ uptake in Phanaenopsis amabilis var. formosa. J. Amer. Soc. Hort. Sci. 131:320-326.

Guo, W.J. 1999. Studies on characteristics of photosynthesis in Phalaenopsis. Master's thesis. Dept. of Hort; National Taiwan Univ., Taipei, Taiwan.

Krizek, D.T. and R.H. Lawson. 1974. Accelerated growth of Cattleya and Phalaenopsis under controlled-environment conditions. Amer. Orchid Soc. Bul. 43:503-510.

Lee, N. 1991. Juvenility in Phalaenopsis. Symp. on Forcing Culture of Hort. Crops II:77-86 (Taiwan).

Lee, N. and C.H. Lee. 1996. Changes in carbohydrates in Phalaenopsis during flower induction and inflorescence development. J. Chinese Soc. Hort. Sci. 42:262-275.

Lee, N. and G.M. Lin. 1984. Effect of temperature on growth and flowering of a Phalaenopsis white hybrid. J. Chinese Soc. Hort. Sci. 30:223-232.

Lin, G.M. and N. Lee. 1988. Leaf area estimation and the effect of temperature on the growth of Phalaenopsis leaves. J. Chinese Soc. Hort. Sci. 34:73-80.

Lootens, P. and J. Heursel. 1998. Irradiance, temperature, and carbon dioxide enrichment affect photosynthesis in Phalaenopsis hybrids. HortScience 33:1183-1185.

Ota, K., K. Morioka, and Y. Yamamoto. 1991. Effects of leaf age, inflorescence, temperature, light intensity, and moisture conditions on CAM photosynthesis in Phalaenopsis. J. Jpn. Soc. Hort. Sci. 60:125-132.

Sakanishi, Y., H. Imanishi, and G. Ishida. 1980. Effect of temperature and flowering on Phalaenopsis amabilis. Bul. Univ. Osaka Pref. Ser. B. 32:1-9.

Wang, Y.T. 2004. Potted orchids continue to rise worldwide. Flower Tech. 7:14-17.

Wang, Y.T. 2005. Temperature and nutrient effects on Phalaenopsis. Proceedings of 2005 Taiwan International Orchids (Paphiopedilum and Phalaenopsis) Symposium. p. 249-258.

United States Department of Agriculture (USDA). 2006. Floriculture Summary. USDA Statistical Service, Washington, D.C. 